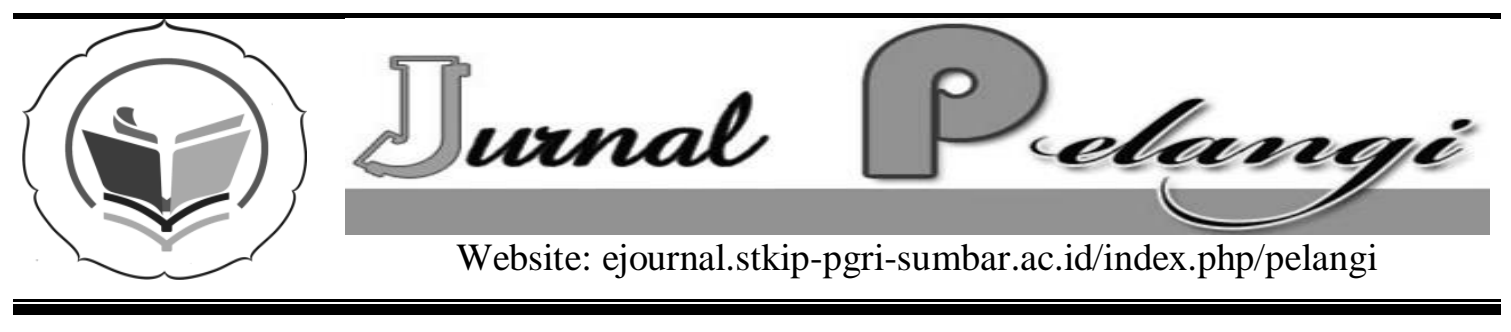

\title{
RANCANGAN MODUL BERBASIS CTL DISERTAI PETUNJUK PENGGUNAAN SOFTWARE R UNTUK PERKULIAHAN STATISTIKA DASAR
}

\author{
Sefna Rismen, Siskha Handayani, dan Hafizah Delyana \\ STKIP PGRI Sumatera Barat \\ sefnarismen@ stkip-pgri-sumbar.ac.id
}

\section{INFO ARTIKEL}

\section{Diterima:}

15 Juni 2017

Direview:

18 Juni 2017

Disetujui:

31 Agustus 2017

Kata Kunci:

Statistik Dasar, Modul, Software R, CTL
Keywords:

\begin{abstract}
Abstrak
Statistika merupakan salah satu cabang ilmu matematika yang mempelajari tentang pengumpulan data, pengolahan, penganalisaan data, serta penarikan kesimpulan berdasarkan hasil analisis. Statistika mempunyai peranan penting dalam melakukan research atau penelitian, oleh karenanya statistika perlu dikuasai dengan baik oleh mahasiswa. Penelitian ini bertujuan untuk menghasilkan rancangan bahan ajar untuk perkuliahan Statistika Dasar di Program Studi Pendidikan Matematika STKIP PGRI Sumatera Barat. Bahan ajar tersebut berguna untuk membantu mahasiswa dalam memahami materi perkuliahan, melakukan pengolahan data dan dapat meningkatkan kemampuan berpikirnya untuk menyelesaikan masalah. Penelitian ini merupakan penelitian pengembangan menggunakan model rancangan 4-D (define, design, develop dan disseminate). Penelitian ini dibatasi sampai pada tahap design. Pada tahap define dilakukan analisis RPS dan buku teks, merevie literatur, serta wawancara teman sejawat dan mahasiswa. Berdasarkan hasil pada tahap pendefinisian diperoleh kesimpulan bahwa diperlukan bahan ajar berupa modul untuk memudahkan mahasiswa dalam memahami materi pada perkuliahan Statistika Dasar. Bahan ajar yang dikembangkan berupa modul berbasis CTL yang disertai dengan penggunaan software $R$. Pada tahap design dihasilkan suatu rancangan modul statistika dasar berbasis CTL disertai petunjuk penggunaan software $R$.
\end{abstract}

\section{Abstract}

Statistics is one of the branches of mathematics that learn 
Elementary of

Statistics, Module,

Software R, CTL about data collection, processing, analyzing data, and drawing conclusions based on analysis results. Statistics have an important role in research, therefore statistics need to be mastered well by students. This study aims to produce the design of teaching materials for Elemantary Statistics lectures in Mathematics Education Studies Program STKIP PGRI Sumatera Barat. Teaching materials are useful to assist students in understanding the course materials, perform data processing and can improve his thinking ability to solve problems. This research is a development research using 4-D design model (define, design, develop and disseminate). This study is limited to the design stage. In the define stage, RPS and textbook analysis, literature review, and colleague and student interviews are conducted. Based on the results at the definition stage obtained the conclusion that the required teaching materials in the form of modules to facilitate students in understanding the material on Basic Statistics lectures. Learning materials developed in the form of CTL-based modules that are accompanied by the use of software $R$. In the design stage generated a draft elementary statistical module based on CTL accompanied by instruction software usage $R$.

\section{PENDAHULUAN}

Statistika merupakan cabang pengetahuan yang sangat dibutuhkan dalam kehidupan sehari-hari dan digunakan dalam berbagai bidang, sehingga manusia tidak bisa terlepas dari penggunaan statistika itu sendiri. Mavrotheris (2007:113) menyatakan bahwa statistika menjadi fokus dalam reformasi pendidikan matematika sebagai aspek yang penting dalam kehidupan sehari-hari. Statistika merupakan salah satu cabang ilmu matematika yang mempelajari tentang pengumpulan data, pengolahan, penganalisaan data, serta penarikan kesimpulan berdasarkan hasil analisis data (Sudjana, 1996). Statistika mempunyai peranan penting dalam melakukan research atau penelitian, serta pengolahan data. Oleh karena itu statistika perlu dikuasai dengan baik oleh mahasiswa.

Melalui perkuliahan Statistika Dasar diharapkan mahasiswa dapat memahami tentang konsep dasar statistika, mendeskripsikan data, menyajikan dan menganalisis data serta menarik kesimpulan. Selain itu mahasiswa diharapkan dapat meningkatkan kemampuan menggunakan software dalam melakukan pengolahan data, penyajian data ke dalam bentuk grafik, dan analisis data. Sekarang ini banyak software atau program yang berkembang yang dapat membantu kita dalam melakukan pengolahan data, penyajian data ke dalam bentuk grafik, dan analisis data. Diantara beberapa software yang ada, ada software yang gratis dan ada yang berbayar.

$\mathrm{R}$ merupakan versi gratis dari bahasa $\mathrm{S}$ dari software berbayar yang sejenis yakni S-PLUS (Alzola dan Harrel, 2006;4). R memiliki fitur yang lengkap dan handal yang dapat membantu kita dalam melakukan pengolahan data, penyajian data ke dalam bentuk grafik, dan analisis data. Selain itu faktor tanggung jawab moral dan legal/hukum tidak lagi menjadi kekhawatiran dalam penggunaan $\mathrm{R}$, karena dapat diperoleh secara gratis. 
Menurut Ihaka dan Gentleman (1996), ada beberapa alasan mengapa menggunakan $\mathrm{R}$, diantaranya adalah :

$\mathrm{R}$ adalah bahasa pemograman, sehingga tidak ada batasan bagi pengguna untuk memakai prosedur yang hanya terdapat pada paket-paket standar

Analisis data membutuhkan pengoperasian yang interaktif. $\mathrm{R}$ dilengkapi dengan konektivitas ke database server, olap, maupun

$\mathrm{R}$ hampir seluruhnya kompatibel dengan S-Plus. Sebagian besar kode program yang dibuat oleh $\mathrm{S}$ dapat dijalankan di S-Plus kecuali fungsifungsi yang sifatnya add-on packages atau tambahan yang dibuat oleh contributor proyek $\mathrm{R}$.

$\mathrm{R}$ adalah bahasa yang paling popular digunakan oleh peneliti di bidang statistika. Beberapa tulisan berupa jurnal statistika mengkonfirmasi kebenaran hal ini. $\mathrm{R}$ juga popular untuk aplikasi kuantitatif dibidang keuangan.

Mahasiswa diharapkan mampu memahami materi pada mata kuliah Statistika Dasar secara keseluruhan. Pemahaman mahasiswa tersebut didapatkan dari belajar mandiri tanpa mengharapkan dosen mentransfer seluruh materi secara keseluruhan. Hal ini disebabkan karena proses perkuliahan di Perguruan Tinggi dituntut usaha mandiri dari mahasiswa sehingga pembelajaran tidak membosankan.

Kenyataan yang terjadi, masih banyak mahasiswa yang memperoleh nilai rendah. Hal ini dapat dilihat pada Tabel 1 berikut.

Tabel 1 menunjukkan bahwa mahasiswa yang memperoleh nilai kurang dari 65 (kategori C, D, dan E) sebesar $54,28 \%$ dan $66,51 \%$. Kenyataan ini masih jauh dari harapan.

Penggunaan Statistika sudah merambah semua bidang ilmu, namun penguasaan mahasiswa belum memuaskan, hal ini di jelaskan oleh
Leibman (2010:15) pembelajaran statistika masih diajarkan secara tradisional dan model transfer pengetahuan masih tetap menjadi mentode andalan. Selanjutnya Leibman (2010:4) menjelaskan untuk mempelajari suatu pengetahuan seharusnya dihubungkan dengan dunia nyata serta dijelaskan aplikasinya.

Permasalahan lain yang sering muncul dalam perkuliahan statistika dasar adalah lemahnya kemampuan mahasiswa dalam menggunakan kemampuan berpikirnya untuk menyelesaikan masalah. Mahasiswa cenderung dijejali dengan berbagai informasi yang menuntut hapalan saja. Banyak sekali pengetahuan dan informasi yang dimilikinya tetapi sulit untuk dihubungkan dengan situasi yang mereka hadapi. Buku ajar yang ada masih bersifat terjemahan sehingga belum menumbuhkan minat mahasiswa untuk mempelajari.

Berdasarkan uraian di atas, maka perlu dilakukan pengembangan modul Statistika Dasar berbasis Contextual Teaching and Learning (CTL) disertai petunjuk penggunaan software R. Pada penelitian ini dirancang modul yang dapat memudahkan mahasiswa dalam memahami materi, melakukan pengolahan data dan dapat meningkatkan kemampuan belajar mandiri.

\section{METODE PENELITIAN}

Penelitian ini merupakan penelitian dan pengembangan (Research and development /R\&D). Menurut Sugiyono (2008:407), "R\&D adalah metode pelitian yang digunakan untuk menghasilkan produk tertentu, dan menguji keefektifan produk tersebut". Produk yang akan dikembangkan dalam penelitian ini adalah alat bantu perkuliahan yang berupa modul berbasis CTL disertai petunjuk penggunaan software R. 
Penelitian ini menggunakan rancangan penelitian pengembangan dengan model pengembangan 4-D rancangan Thiagarajan, Semmel, dan Semmel (Trianto, 2007: 65). Model pengembangannya terdiri atas 4 tahap yang meliputi: pendefinisian (define), perancangan (design), pengembangan (develop), dan penyebaran (desseminate). Tahap-tahap yang akan dilalui peneliti hanya sampai tahap design. Secara lengkap prosedur yang akan dilakukan sebagai berikut ini.

\section{Pendefinisian (define)}

Kegiatan yang dilakukan pada tahap ini adalah sebagai berikut.

1. Menganalisis RPS, hal ini bertujuan agar pada pengembangan bahan ajar berupa modul berbasis CTL disertai penggunaan software $\mathrm{R}$ sesuai dengan Capaian Pembelajaran (CP) yang harus dicapai Mahasiswa

2. Menganalisis buku teks Statistika Dasar, untuk melihat kesesuaian isi buku dengan standar kompetensi dan kompetensi dasar yang harus dicapai mahasiswa.

3. Mereview literatur yang terkait dengan pengembangan modul, untuk melihat rujukan mengenai modul.

4. Melakukan wawancara dengan teman sejawat dan mahasiswaan, ini bertujuan untuk mengetahui masalah/hambatan apa saja yang dihadapi di lapangan sehubungan dengan perkuliahan Statistika Dasar.

\section{Perancangan (design)}

Modul dibuat terdiri dari empat bagian yang dapat dipergunakan untuk satu semester, bagian-bagiannya yaitu: modul 1 Konsep dasar statistika; modul 2 tentang Penyajian data; modul 3 tentang Pendeskripsian; modul 4 tentang Teori Peluang. Masing-masing modul berisi standar kompetensi, uraian materi, contoh soal, latihan mandiri, umpan balik, tindak lanjut, dan kunci jawaban. Setiap modul terdiri atas beberapa kegiatan belajar yang sudah disesuaikan dengan silabus.

\section{HASIL DAN PEMBAHASAN}

Analisis RPS bertujuan untuk mengidentifikasi materi pada perkuliahan Statistika Dasar yang dijadikan acuan untuk menyusun secara sistematis konsep-konsep materi pada modul berbasis CTL disertai penggunaan software R. Capaian pembelajaran mata kuliah berdasarkan tahapan belajar adalah:

1. Mendefinisikan dan membedakan statistik dan statistika

2. Membedakan statistika deskriptif dan inferensial

3. Mendefinisikan populasi, sampel, sensus, dan sampling

4. Membulatkan sebuah bilangan dengan menggunakan aturan pembulatan

5. Mendefinisikan dan membedakan macam-macam tabel

6. Membuat diagram batang, histogram, polygon, garis dan lingkaran.

7. Menginterpretasikan table dan diagram

8. Mengubah data tunggal menjadi data kelompok

9. Menghitung banyak kelas, jangkauan, dan panjang kelas

10. Membuat table distribusi frekuensi relative

11. Membuat table distribusi frekuensi kumulatif

12. Membuat histogram, polygon frekuensi, dan ogive

13. Menghitung rata-rata, median, modus, kuartil, desil, persentil,

14. rentang/jangkauan, rentang antar kuartil, rata-rata simpangan, simpangan baku, dan variansi. 
15. Menentukan peluang suatu kejadian dengan menerapkan beberapa hokum peluang

16. Menerapkan aturan peluang bersyarat dan kaidah Bayes dalam berbagai permasalahan yang diberikan

Analisis buku teks bertujuan untuk melihat kesesuaian isi buku dengan standar komptensi dan kompetensi dasar yang harus dicapai mahasiswa. Berdasarkan analisis buku teks yang dilakukan untuk dua buku teks wajib mahasiswa yakni Pengantar Statistika, karangan Ronald Walpole dan Metode Statistika karangan Sudjana. Hasil analisis buku untuk kedua buku teks tersebut secara umum disimpulkan sebagai berikut:

1. Judul belum sepenuhnya mencerminkan KD yang harus dicapai.

2. Topik/sub topik belum terurut sesuai dengan silabus atau komptensi yang akan dicapai.

3. Penilaian belum masih bersifat umum dan belum tersturktur sesuai dengan tngkat kemampuan

4. Uraian materi pada setiap bab belum memotivasi mahasiswa untuk belajar serta belum mengkonstruk pengetahuan mahasiswa

5. Cakupan materi setiap bab belum memenuhi pencapaian KD

6. Uraian materi pada buku belum membuat mahasiswa bisa belajar mandiri

7. Bahasa yang digunakan dalam penyajian materi terkadang sulit dipahami baik dosen maupun mahasiswa.

8. Penilian yang digunakan belum mencakupi ketiga ranah pengetahuan (pengetahuan/kognitif, afektif belum ada, keterampilan)

Hasil wawancara mahasiswa
Analisis ini dilakukan untuk memudahkan menyusun rancangan pengembangan bahan ajar. Data dikumpulkan melalui wawancara. Hasil wawancara diperoleh hasil sebagai berikut:

1. Bahasa yang digunakan dalam buku teks sebagai buku wajib dalam perkuliahan secara umum responden menyatakan kesulitan dalam memahami materi, karena buku tersebut merupakan buku terjemahan;

2. Pendapat mahasiswa dalam bentuk penyajian dari buku teks memiliki pendapat yang berbeda-beda. Hal ini dapat dilihat dari penilaian yang dilakukan oleh mahasiswa yang mendapat nialai bagus, kebanyak mahasiswa memiliki pendapat bahwa buku teks sudah sistematis, namum bagi mahaiswa yang memiliki nilai yang kurang bagus kebanyakan mereka memiliki pendapat bahwa penyajian buku teks masih sulit dipahami dan kurang sistematis;

3. Kelengkapan materi dari buku teks kebanyak mahasiswa berpendapat bahwa isi/kelengkapan materi buku teks belum lengkap;

4. Tingkat kesulitan soal yang ada secara keseluruhan mahasiswa juga menyatakan soal-soal yang ada pada buku teks masih sulit dipahami terutama bahasa yang digunakan , walau ada beberapa yang bisa diselesaikan;

5. Harapan mahasiswa tentang bahan ajar yang mereka harapan adalah bahan ajar dapat membantu memahami materi kuliah dan bisa belajar sendiri seperti modul. Mahasiswa juga berpendapat bahwa bahan ajar yang bersifat mengkonstruk dan menemukan konsep juga bagus digunakan ; 
6. Secara keseluruhan mahasiswa tidak ada menggunakan software dalam pengolahan data, dan mereka juga tdak pernah mengenal software R;

7. Pandangan mahasiswa tentang modul berbasis CTL yang diikuti dengan penggunaan sofware $R$ sangat bagus sekali digunakan dalam perkuliahan agar materi mudah dipahami.

Review literatur bertujuan sebagai bahan rujukan dalam mengembangkan bahan ajar. Kegiatan review literatur yang dilakukan adalah mengumpulkan bahan-bahan /referensi yang terkait dengan penyusunan modul statistika berbasis Contekxtual teaching and learning (CTL). Ada beberapa literatur yang dirujuk selain buku teks wajib diantaranya:

1. Panduan kreatif membuat bahan ajar inovatif yang disusun oleh Andi Prastowo tahun 2011.

2. Menyusun Modul oleh Daryanto tahun 2013.

3. Model pembelajaran terpadu oleh Trianto tahun 2010.

4. Pengembangan Bahan ajar oleh Depdiknas 2006

5. Pengertian fungsi dan tujuan modul oleh Rosyid tahun 2010

6. buku - buku sekolah (SD, SMP, dan SMA)) ini digunakan sebagai bahan masukan dalam penambahan materi buku-buku teks yang digunakan

7. Jurnal-jurnal tentang CTL

8. Panduan penggunaan sofware $\mathrm{R}$ dan artikel-artikel tentang sofware R.

Dengan menganalisis literaturliteratur di atas, maka dikembangkan bahan ajar berupa modul statistika dasar berbasis CTL yang diikuti dengan penggunaan software $\mathrm{R}$.

Wawancara dengan teman sejawat dilakukan untuk melihat permasalahan/ hambatan dalam perkuliahan, dalam hal ini dilakukan dengan teknik wawancara, Hasil wawancara yang dilakukan diperoleh hasil sebagai berikut:

1. bahasa yang digunakan buku teks yang digunakan selama ini sulit dipahami/dimengerti;

2. bentuk penjajian dari buku teks sudah sistematis tetapi masih ada yang kurang lengkap, penyajian belum menkonstruksi pengetahuan mahasiswa serta mahasiswa belum diarahkan untuk menemukan konsep;

3. ditinjau dari kelengkapan materi secara umum materi sudah lengkap;

4. tingkatan kesulitan soal/latihan secara umum mudah dipahami tetapi masih ada yang sulit dipahami;

5. bahan ajar yang diharapkan adalah bahan ajar adalah berupa modul karena dengan modul mahasiswa bisa belajar mandiri;

6. rata-rata dosen sudah menggunakan software dalam pengolahan data terutama MINITAB dan SPSS, tetapi belum pernah menggunakan software R;

7. tanggapan dosen tentang modul berbasis CTL yang diikuti dengan penggunaan software $\mathrm{R}$ adalah sangat bagus sekali karena lebih memudahkan mahasiswa dalam memahami materi ajar.

Modul dibuat terdiri dari empat bagian yang dapat dipergunakan untuk satu semester, bagian-bagiannya yaitu: modul 1 Konsep dasar statistika; modul 2 tentang Penyajian data; modul 3 tentang Pendeskripsian; modul 4 tentang Teori Peluang. Masing-masing modul berisi standar kompetensi, uraian materi, contoh soal, latihan mandiri, umpan balik, tindak lanjut, dan kunci jawaban. Setiap modul terdiri atas beberapa kegiatan belajar yang sudah disesuaikan dengan silabus. Masing-masing modul berisi Capaian Pembelajaran (CP), 
uraian materi, contoh soal, latihan mandiri, umpan balik, tindak lanjut, dan kunci jawaban. Setiap modul terdiri atas beberapa kegiatan belajar yang sudah disesuaikan dengan RPS. Modul yang sudah dirancang memiliki struktur sebagai berikut.

Cover modul dibuat dengan menggunakan Photoshop. Cover modul dirancang menggunakan warna biru, merah dan gambar yang mewakili isi modul. Judul yang terdapat pada cover adalah adalah modul statistika berbasis Contextual Teaching and Learning. Judul pada cover modul memberikan identitas dari modul yang dirancang. Modul ini untuk mahasiswa Program

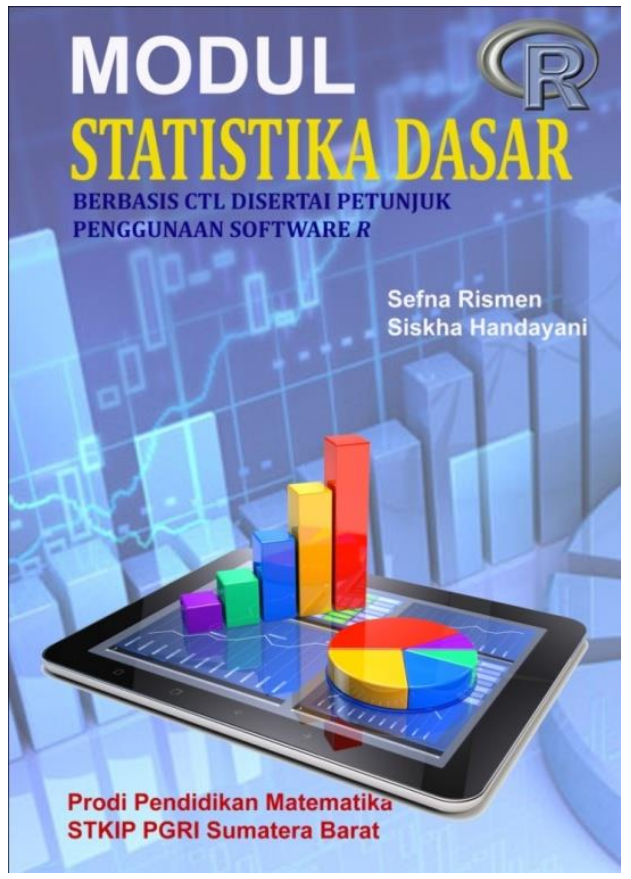

Gambar 1. Cover modul
Studi Pendidikan Matematika STKIP PGRI Sumatera Barat. Tampilan cover modul Statistika berbasi Contextual Teaching and Learning disertai penggunaan software $\mathrm{R}$ dapat dilihat pada Gambar 1.

Petunjuk Modul berisi petunjuk yang harus dilakukan mahasiswa dalam belajar dengan menggunakan modul ini. Penyajian petunjuk penggunaan modul dapat dilihat pada Gambar 2.

Materi pelajaran pada modul dirancang sesuai dengan komponen pendekatan Contextual Teaching and Learning yang dirangkum sebagai berikut.

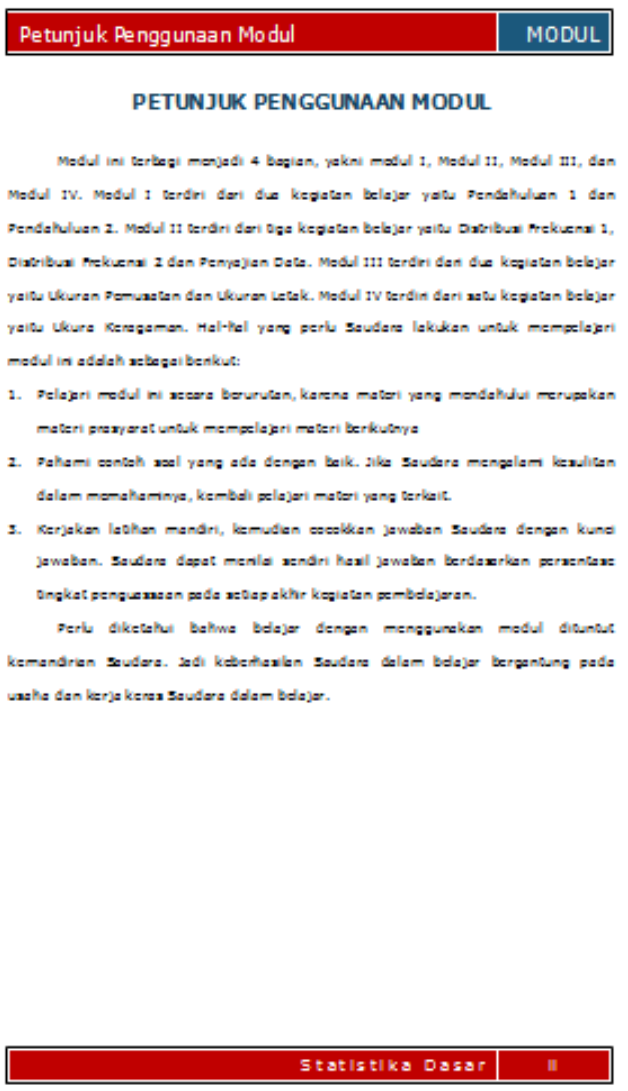

Gambar 2. Petunjuk Penggunaan Modul 


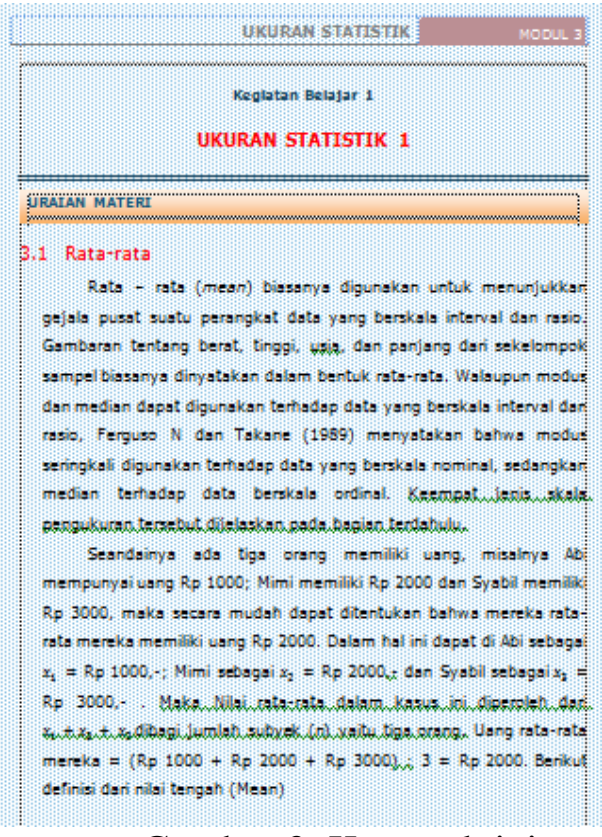

Gambar 3. Konstruktivisme

\section{Kontruktivisme}

Komponen ini merupakan landasan filosofi (berpikir) pendekatan Contextual Teaching and Learning. Pembelajaran yang berciri kontruktivisme menekankan terbangunnya pemahaman sendiri secara aktif, kreatif, dan produktif berdasarkan pengetahuan terdahulu dan dari pengalaman belajar. Contoh kegiatan konstruktivisme dalam modul dapat dilihat pada Gambar 3.

\section{Menemukan}

Komponen inkuiri merupakan kegiatan inti kontekstual. Kegiatan ini diawali dari pengalaman terhadap fenomena, dilanjutkan dengan kegiatan bermakna untuk menghasilkan temuan yang diperoleh mahasiswa. Contoh kegiatan menemukan dalam modul dapat dilihat pada Gambar 4.

\section{Bertanya}

Bertanya dalam pembelajaran Contextual Teaching and Learning dipandang sebagai upaya untuk mendorong siswa mengetahui sesuatu, mengarahkan mahasiswa memperoleh informasi, sekaligus mengetahui perkembangan kemampuan berpikir

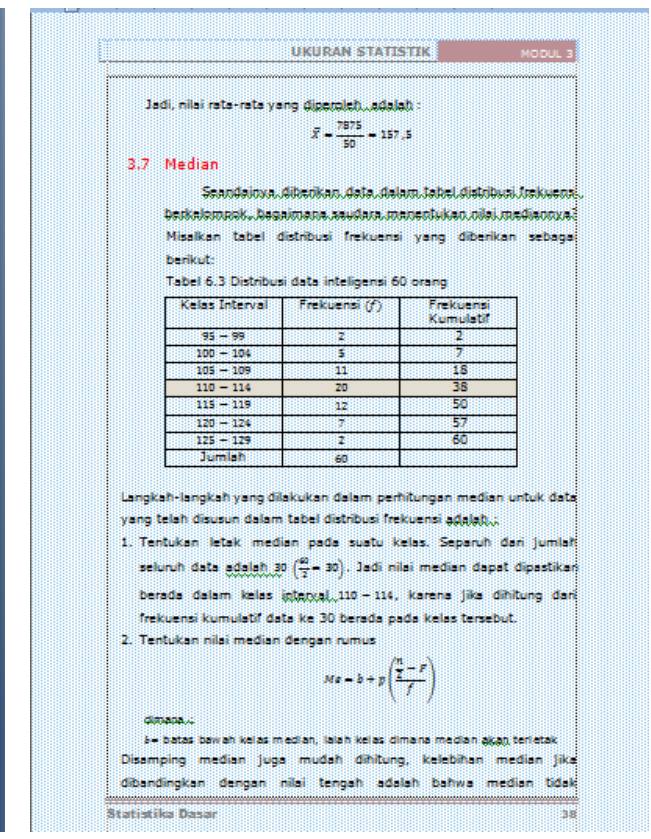

Gambar 4. Menemukan

siswa. Gambar 5 menunjukkan kegiatan bertanya dalam modul.

\section{Penggunaan Software $R$}

Penggunaan Software $\mathrm{R}$ berisikan petunjuk penginstallan Software $\mathrm{R}$ dan langkah-langkah dalam pengolahan data dengan menggunakan Software R. Salah satu contoh pengolahan data dengan software R dapat dilihat pada Gambar 6 dan Gambar 7.

\section{Pembahasan}

Berdasarkan deskripsi data yang telah diuraikan di atas tentang pendapat dosen dan mahasiswa tentang buku teks yang digunakan dalam perkuliahan Statistika Dasar secara keseluruhan buku teks yang digunakan dilihat dari segi bahasa, penyajian materi, kelengkapan isi, serta soal-soal yang ada, masih sulit dipahami dan belum membatu mahasiswa untuk bisa belajar mandiri. Hal ini tentu membuat mahasiswa kesulitan memahami materi ajar dan akan berdampak pada hasil belajar yang mereka peroleh. Oleh karenanya, diperlukan bahan ajar yang mudah dipahami dan bisa dipelajari sendiri. Bahan ajar tersebut dapat berupa modul, karena modul adalah suatu bahan ajar 
yang disusun secara sistematis, sesuai dengan karakteristik dan kebutuhan siswa. Modul juga dapat dapat mengontrol intesintas belajar siswa, dan dapat digunakan dimana saja. Hal ini sesuai dengan harapan dosen dan mahasiswa tentang bahan ajar yang dapat membantu dalam memahami materi ajar dengan demikian diharapkan hasil pembelajaran dapat memuaskan. Agar pengetahuan mahasiswa berkembang dan bertahan lama dalam ingatannya maka, modul yang dibuat dapat berupa modul berbasis Contexstual Teaching and learning (CTL). Karena dengan pendekatan CTL dapat mengkostruk pengetahuan mahasiswa dan menemukan konsep dari materi serta dapat membuat pemodelan sendiri dengan demikian konsep akan bertahan dalam pengetahuan mahasiswa.

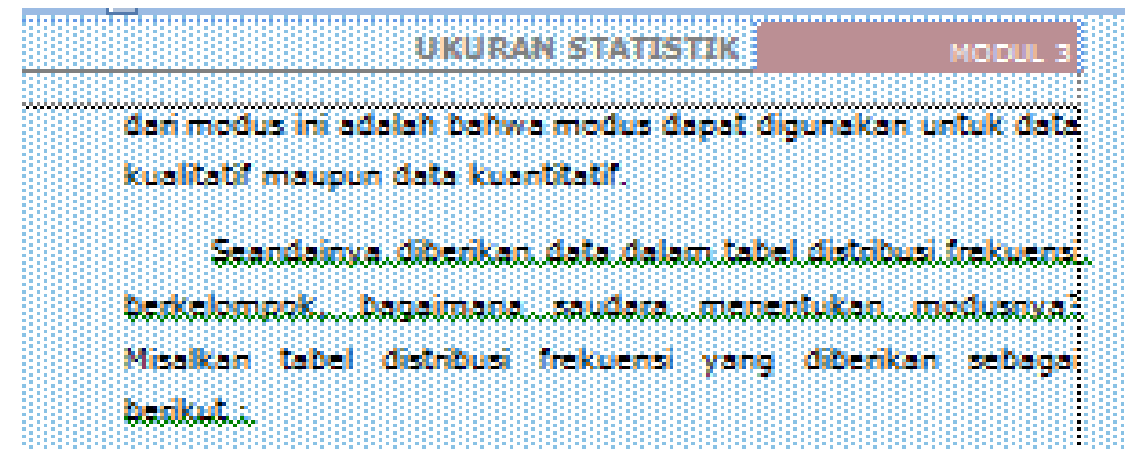

Gambar 5. Bertanya

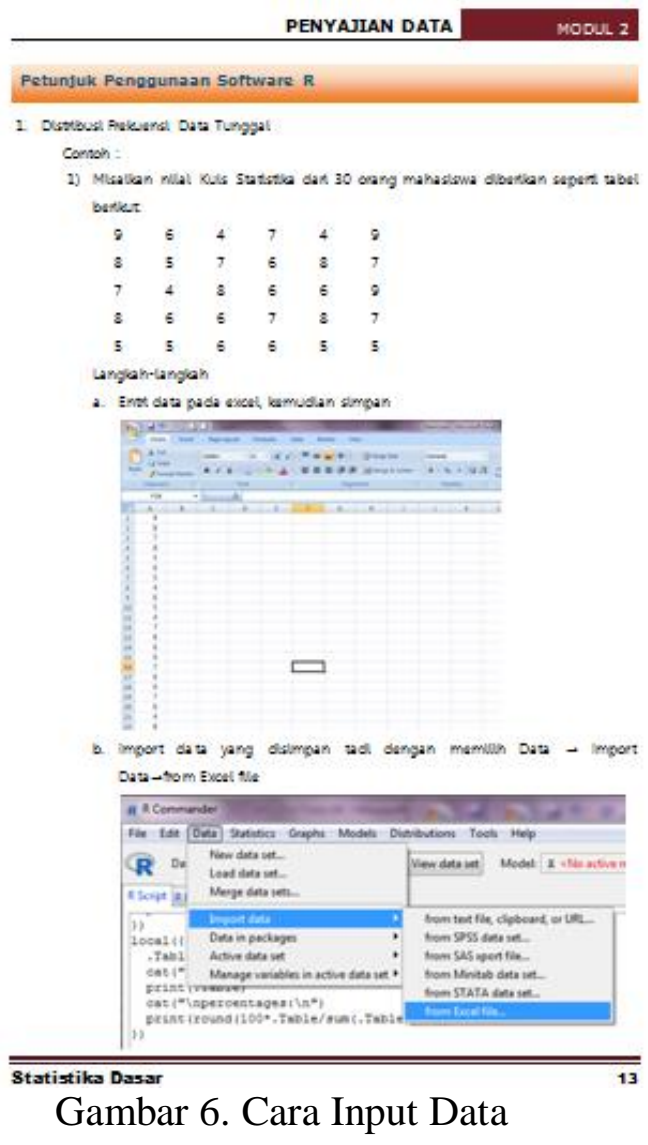

Gambar 6. Cara Input Data

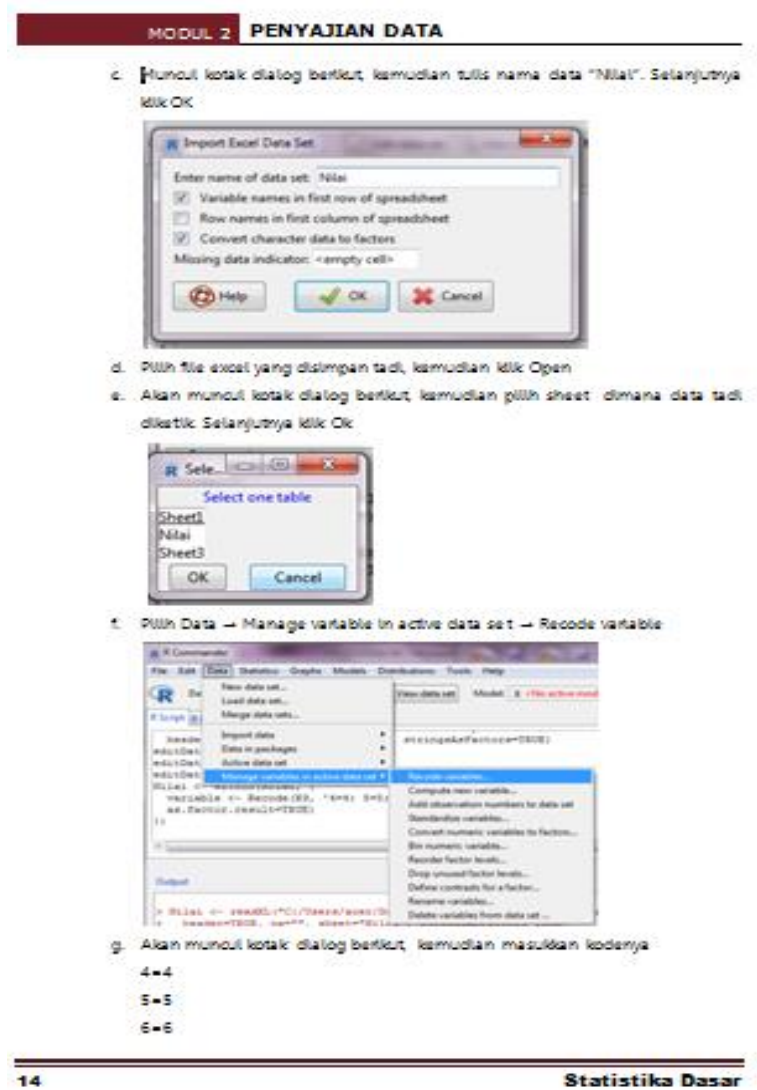

Gambar 7. Pengolahan data dengan Software R 
Modul yang dirancang juga menggunakan teknologi sebagai alat bantu dalam pengolahan data dalam hal ini menggunakan software R. Sofware R ini dipilih karena software ini mudah didapat tanpa biaya atau software yng free bisa di download sendiri dan software ini juga belum familiar sebagai alat pengolah data penelitian. Oleh karenanya modul ini juga diberikan petunjuk penggunaan sofware $\mathrm{R}$ disetiap uraian materi.

\section{PENUTUP}

Berdasarkan hasil pada tahap pendefinisian diperoleh kesimpulan bahwa diperlukan bahan ajar berupa modul untuk memudahkan mahasiswa dalam memahami materi pada perkuliahan Statistika Dasar. Bahan ajar yang dikembangkan berupa modul dengan berbasis CTL yang disertai dengan penggunaan software $\mathrm{R}$. Sedangkan pada tahap design sudah dirancang modul Statistika Dasar berbasis CTL disertai petunjuk penggunaan software $\mathrm{R}$ yang sesuai dengan kebutuhan bahan ajar pada perkuliahan Statistika Dasar.

\section{UCAPAN TERIMA KASIH}

Terbitnya tulisan ini tidak terlepas dari bantuan berbagai pihak, untuk itu penulis ucapkan terima kasih kepada UP3M STKIP PGRI Sumatera Barat dan pengelola jurnal Pelangi yang telah memberikan saran dan revisi dalam penulisan artikel ini.

\section{DAFTAR PUSTAKA}

Alzola, C., and F. Harrell. 2006. An Introduction to $\mathrm{S}$ and The Hmisc and Design Libraries. http://biosfat.mc.vanderbilt.edu/RS

Ihaka Ross dan Robert Gentleman. 1996. R: A Language for Data Analysis and Graphics. Journal of Computational and Graphical Statistics. Volume 5. No. 3: 299314.

Leibman, Zipora. 2010. Integrating RealLife Data Analysis in Teaching Descriptive Statistics: A Constructivist Approach. Journal of Statistic Education. 18, (1). www.amstat.org/publications/jse/v 18n1/libman.pdf

Mavrotheris, M.m dan Mavrotheris, E, 2007. Online Communities of Practice Enhancing Statistics Instruction: the European Project Early Statitics. The Electronic Journal of e- learning. Vol 5, No 2:113-122

Nana, Syaodih Sukmadinata. (2010). Metode Penelitian. Bandung: Remaja Rosdakarya.

Sudjana. 1996. Metoda Statistika. Bandung: Transito

Sugiyono. 2008. Metode Penelitian Pendidikan. Bandung: CV. Alfabeta

Trianto. 2007. Mendesain Model Pembelajaran Inovatif-Progresif: Konsep, Landasan, dan Implementasinya pada Kurikulum Tingkat Satuan Pendidikan (KTSP). Jakarta: Kencana 